\title{
TBXT wt Allele
}

National Cancer Institute

\section{Source}

National Cancer Institute. TBXT wt Allele. NCI Thesaurus. Code C84456.

Human TBXT wild-type allele is located in the vicinity of $6 \mathrm{q} 27$ and is approximately $11 \mathrm{~kb}$ in length. This allele, which encodes $\mathrm{T}$-box transcription factor $\mathrm{T}$ protein, plays a role in the regulation of transcription during mesoderm formation and differentiation. Gene duplication is associated with familial chordoma. 